\title{
BOOKKEEPING CHARACTERISTICS OF THE EDUCATIONAL EDITIONS FROM THE OLD PRINTING COLLECTION OF COMMUNITY CENTER “NADEZHDA" - VELIKO TARNOVO
}

\author{
Zhivka Radeva \\ "St. Cyril and St. Methodius" University of Veliko Tarnovo \\ z_radeva@abv.bg
}

\begin{abstract}
The article presents the way in which the educational editions are constructed, the overall layout of the book body and the fragments that make it up - the information value of the title, the organization and the structure of the text volumes; the place of illustration in the structure of the Revival textbook. In view of the authorship, this part of the old printed collection of Community center "Nadezhda" provides information about the popular names in the educational program of the XIX century. The branch and thematic orientation of the textbooks, in turn, highlight the educational priorities and the reading attitudes in Tarnovo during the Revival. With these characteristics, the educational books from the old printed collection of Community center "Nadezhda" become an essential element of the literary atmosphere in Tarnovo and the Revival culture. They are a valuable literary and documentary heritage and a good research base for book publishing, readers and reading during the Renaissance.

Keywords: Community Center "Nadezhda", Veliko Tarnovo; Literary and Documentary Heritage; Bulgarian Book Publishing During the Revival
\end{abstract}

\section{КНИГОВЕАСКА ХАРАКТЕРИСТИКА НА ПРОСВЕТНИТЕ ИЗААНИЯ ОТ СТАРОПЕЧАТНАТА КОАЕКЦИЯ НА ЧИТААИЩЕ „НААЕЖАА“ - ВЕАИКО ТЪРНОВО Живка Ралева \\ ВТУ „Св.Св. Кири^ и Методий“, В. Търново, България}

\begin{abstract}
Резюме: Статията представя начина, по който са конструирани просветните изАания, цялостното офрормление на книжното тяло и фррагментите, които го изгражАат инфрормационната стойност на титула, организацията и структурата на текстовите обеми; мястото на илюстрацията в структурата на възрожАенския учебник. С оглеА на авторството тази част от старопечатната колекция на читалище "НалежАа" инфрормация за популярните имена в образователната програма
\end{abstract}


на XIX век. Отрасловата и тематичната ориентация на учебниците открояват образователните приоритети и читателските нагласи в Търново през Възраждането. С тези свои характеристики просветните книги от старопечатната колекция на читалище "Належла" се преврьщат в същностен елемент от книжовната атмосорера в Търново и от възрожленската култура. Те са ценно Книжовно-АОКУментално наслеАство и Аобра изслеАователска база относно КнигоизАаването, читателите и четенето.

КАючови Ауми: читалище „НадежАа", Велико Търново; книжовно-Аокументално наслеАство; българско книгоизАаване през ВъзражАането

Старопечатните книги в библиотеката на читалище „НалежАа“ са поларени от родолюбиви българи и са Ауховна опора на търновчани в годините преАи освобожАението от османско вАаАичество. В началото на XXI век те все още са в много Аобро състояние: вторично подвързани и очевиАно грижливо пазени. Анес гледаме на тях като на книжовноАокументално наследство и добра изследователска база относно книгоизАаването, читателите и четенето през Възраждането. Компактна група среА тях са просветните изАания (78 на брой), съзАалени за 40годишен периол (1835-1875 г.). В своята общност те Аават възможност $А а$ се направят наблюдения за начина, по който се конструират пьрвите български учебници във времето на тяхното създаване; за цялостното одрормление на книжното тяло и оррагментите, които го изгражАат.

През Възраждането традициите се ползват с пьлна си^а, в същото време се усвоява и чужла книжовна култура, като целта е постигане на „ускорено обществено и Ауховно развитие"l (Gachev, 1979: р. 21 ). Аипсата на Аьржава и институции е причина за разгръщане на частни ИзАателски Инициативи в полза на интелектуалния напреАък на народа. Автори, изАатели и книжари са с идеята, че имат мисия относно „белите полета" в българската книжнина и Аават всичко от себе си, за $А а$ увеличат отрасловото знание, постигнато през годините на роден и разбираем език, в Аостьпна книжна форма. ИзАаването на учебници и учебни помагала е продиктувано от рационални илеи, свързани с промените в културата на четене, с осъзнатата необходимост от масова просвета.

\footnotetext{
${ }^{1}$ Гачев, Г. Ускорено развитие на културата. - С., 1979, с. 21, (Gachev, 1979: р. 21).
} 
По тази причина просветните книги са фундамент в националната издателска програма през Възраждането. Те популяризират знанието и културата на времето, носители са на нови илеи, на важните национални приоритети. Големият брой на изАалените учебници свързваме с нужАите на българското общество, с желанието $\Delta a$ се пише за всичко, което е добро и полезно, с осъзнатия стремеж $\Delta а$ се уловлетворят поривите кьм просвета и духовен напредьк на народа ни. Като типова структура учебниците са важна част от издателските почини слеА 1835 г.2 (Pogorelov, 1923), когато се популяризира взаимообучителния метол и се увеличава броят на тьрсещите книги и на четящите. НаблюАенията, характеристиките, коментарите, свързани с колекцията на читалище "Належла", фрормирана на регионален принцип и чрез Аарения, упльтняват представата за книжовната ситуация по цялата българска земя и конкретно в старата столица по време на робството.

Инорормационната стойност на корицата. Сведения за първоначалния виА на просветните изАания се Аобиват трудно, тъй като голяма част са Аостигнали АО нас Със СвоИте слеАОсвобожАенски полвързии. Въпреки това от орорма́та, хартията, печата се получава сравнително реалистична представа за бюАжета, с който са разполагали изАанията и вниманието, проявено Към тях от страна на автори, спомоществователи, издатели, печатари.

В допечатния периол четящите са възпитани с културата на ръкописните книги - кориците са изработени от Аьрво и кожа, с преоблалаващ орнаментален характер, резултат от специализирана и скъпа изработка. Първите ни печатни издания (в голямата си част учебници) имат корица, изработена от обикновен картон или хартия. Въпреки ограниченото фринансиране, в рамките на тралицията орнаменталният иे характер се запазва: Иван Богоров - „Кратка география. Математическа, фризическа и политическа" (Букурещ, 1851 г.); Спас Зафиров - „Практическо изучение фрранцузкий язык по О^енлороровата метолика" (Пловлив, 1862 г.) и Ар.

2 Вж Погорелов, Валерий. Опис на старите печатни български книги. 1802-1877 г. Софии : Аьрж. печатница, 1923. - 795 с., (Pogorelov, 1923) 
Книжните обрези са семпли и непрецизно изпьлнени, без Аопьлнително оцветяване. В колекцията от просветни старопечатни книги на читалище "НалежАа" има и еАно изкАючение - авторският труд на Иванчо Анареов „Първичка българска граматика“ (Букурещ, 1844 г.).

Характерен белег на ранното възрожленско книгоиздаване е отсьствието на фрорзац. В голяма част от учебниците липсва и заглавна страница. Тя най-често е съвместена в енно с корицата, без излишества. По-отчетливи промени в тази практика се забелязват от края на 50-те години на XIX век, когато учебниците с корица и титул стават повече, а заглавната страница повтаря точно коричния текст: Тодор Шишков "Пьрва храна на зАравыят чоляшкій ум" (ЦариграА, 1860 г.); Иван Момчилов - „Граматика за старобългарския йезик по сичкото му развитие“ (Виена, 1865 г.), „Бележки връх граматиката за новобългарския език" (Русчук, 1868 г.), „Малка аритметика“ (Тьрново, 1869 г.) и Аруги.

Самата учебникарска корица е оорормена наглеА непретенциозно, в същото време е явен стремежьт $а$ а се направи найдоброто, което позволява бюджетьт на изданието и печатарските възможности на XIX век - използват се четивни, открояващи се шрифртове при качествен буквен набор и добър печат. Класическата титулна четворка във възрожленските книги се среща рялко, но в просветната старопечатна колекция на читалище „Належла“ има такава - „Кратка географфия, математическа, фризическа и политическа" (Букурещ, 1851 г.) на Иван Богоров.

Кориците на възрожленските учебници са с богато инорормативно сьдьржание, вкАючително и относно тяхното предназначение: „за Аолномахленското училище в Търново“ (Антон Никопит - „Учения за Аецата“ (Цариграл, 1850 г.) ; „за употребленіе на тех, които ся учат на най-Аолныте чинове на Ел^енските училища“ (Христо Златевич - „Опитна числителница“ (Цариграл, 1852 г.). ПреАоставената инорормация има важната залача $А а$ улеснява рецепцията на изАанието и неговата илентифрикация. Значимостта иे се увеличава от липсата на издателско каре. Наблюденията показват, че кориците на просветните книги са преобладаващо шрифртово офрормени („Първичка българска граматика, 1844 г.; „Опитна числителница“, 1852 г. и мр.), без украсни елементи. 
Тенденцията се запазва през целия периол, отличителен белег е типографрското им еАинство - пропорционално разположение на текста, хармонично съвместен с фрорма́та на изаанието. При композирането им е явен стремежьт кьм разделяне на инорормацията в няколко моАулни конструкции с различно сьдьржание, които се отличават графично (чрез използване на различни шрифтове и кегел) и визуално (чрез вертикални отстьпи межАу отАелните инорормационни групи). Текстьт е центриран, симетрично разположен, композиран с цел добро зрително възприятие и баланс („Игиономия сиреч Правила за $А$ с си вардим зАравието", 1846 г.; "Аетинско прибавление или Различни нравствени поучения и нравоучителни истории", 1852 г. и Ар.). Някь $А е$ обособяването на коричните инорормационни групи е акцентирано с фрина черна миния или с фрилигранни мотиви ( „Начални алгебрически уроци“, 1859 г.).

Значението, което се отАава на коричните инорормационни моАули, мичи от тяхното позициониране. Вариативността в това отношение не е голяма. В организацията на корицата на пьрво място стоят заглавията, тъй като „през тези десетилетия в центьра на вниманието, обект на начална сакрализация се оказва не личността на книжовника, а съзАаленото от него съчинение"з (Radev, 2002). По тази причина акцентьт се поема от наАсловите. Те се превръщат в основен смислов и знаков елемент от коричната графикка. Оорормлението им е к^асическо - осово, центрирано, равнено по краищата на наборното поле или по отстьпа на абзаците. Именно заглавията определят и в известен смисьл полчиняват цялостната графична концепция на корицата-титул. За тяхното представяне комбинирано се използват найефректните шрифртове, с които печатницата разполага, както и всякакви полиграфически способи. РазновиАностите се определят от типологията на изданието - учебник, от стила на заглавието и броя на неговите нива: само големи букви с по-голям кегел; рисувани букви (черни, получерни, курсивни), които спират вниманието и се запомнят.

3 Ралев, Иван. Бележки за статута на текста, на авторовата личност. - Ралев, И. Българската митература на XIX век : От анонимност към авторство. - В. Търново, 2002, c. 13., (Radev, 2002) 
Шриортовата заглавна йерархия се определя от сьзАателите на учебника. Графричното и смисловото ударение пала върху важната част, която определя същинското съдьржание на изаанието и е устойчива: антропология („Кратка антропология или Наука за чловека“, 1856 г.); всеобща история („Кратка всеобща история в прости разкази рали юношества“, 1861 г.); география („Кратка география, математическа, фризическа и политическа" (Букурещ, 1851 г.); наставления (Разни полезни наставления за млалите", 1867 г.) и др. Устойчивите заглавия имат пряко и бързо въздействие, тьй като въвежАат понятия, които са познати вече на читателите. Тези части от заглавието са най-активни, дори когато са на втора и^и трета позиция, защото са шрифртово обособени и с по-го^ям размер от останалите. ПреАвиА големия брой устойчиви заглавия, решени композиционно на елин принцип (с изведена сигнална Аума), можем Аа кажем, че това е тенденция за книгопечатането през XIX век. Особено функционална е тя при недостатьчно подготвената аудитория с по-слаба културна асоциативност и при преоблалаващия брой на книги с просветно и религиозно сьАьржание.

Аоста често заглавието е организирано така, че ла отбележи националната приналлежност на текстовете - българска (Неофит Ри^ски - „Болгарская граматика", 1835 г.; Никола Михайловски - „Малка българска читанка", 1866 г.; Сава РаАулов - „Български буквар“, 1866 г.).

Титулната страница инорормира и за преводния характер на събраните текстове: „преведени от србскаго на славено-болгарский язик в ползу славеноболгарскаго юношества от Йоана Стояновича, учителя" (,Аве советователни слова...", Белград, 1845 г.), а също и когато преводьт е направен през език: „пьрвеш преведена на Грьцки от Немски език, а сега от гръцки на български" (,Първа храна на зАравият чоляшкий ум. Школска и Аомашна книга за Аецата" (ЦариграА, 1860 г.). Българските Аобавки също са означени. В редки случаи титульт инорормира за наличието на илюстрации.

Аруг информационен модул върху корицата-титул са мичните имена на автора, на съставителя, преводача, редактора. Тяхното място в текстовата композиция е важно, но очевилно е второстепенно за възрожденския учебник. 
Разнообразието при представянето им е по-голямо - чрез главни, редовни или курсивни букви, а също чрез светли, черни и получерни, като кегельт е 2-3 степени налолу спрямо заглавието и равнен с ползаглавието. Аействащата практика е в пьрвите изАания илентификацията $А$ а е пьлна - с мично, бащино и фрамилно име. Титульт често Аава инорормация за родното място, местоработата и продресията на автора (издателя, преволача): "превелена на българскиіят язык от Савва X. Иліевича Аоброплоднаго сливниънина“ (,Игиономия...", Цариграх, 1846 г.); „собрано от Еммануила Васкиловича, учителя плевненскаго училища" ("Аетинско прибавление“, Цариграл, 1852 г.) и др. Като се има преАвиА авторитетьт на учителската продресия през Възражлането, това представяне вероятно има за цел $а я$ увеличи интереса кьм учебниците.

Следващата индрормационна текстова група е свързана с поредността на изданието. Тя не винаги е означена. Там, където се среща, е във варианти и орормулировки, съответстващи на времето пьрво ("сега перво сочинена", „издание перво“): Неофрит Ри^ски „Болгарска граматика" Крагуевац, 1835 г.), Емануил Васкилович „Аетинско прибавление" (Цариграл, 1852 г.); - второ (Второ исправено изаание“): Сава Ралулов - „Начална граматика..." (Болграл, 1873 г.).

В композицията на корицата-титул се срещат и щрихови рисунки, графично представени орнаменти, единични предмети, които заемат пространството слеА важните текстови инорормационни групи на заглавието и имената на авторите-сьставители. Коричната илюстрация има естетически цели. Тя зальржа вниманието на читателя, придава представителност на книжното тяло, но в редки случаи е посветена на текстовете в учебника.

Четвъртата (послеАна) група от титулната текстова инорормация е позиционирана в Аолния край, в средата на наборното поле и е свързана с печатницата, местопечатането (местоизАаването) и годината на отпечатване. Като начин на представяне тя следва графричната концепция на целия коричен текст. Печатарско лого, изАателска емблема, илентифициращи орирмени графични знаци в просветните книги се откриват рядко. 
Залната корица на възрожленския учебник също има инорормиращи и рекламни фрункции - вкАючва свеАения за изАанието, за Аруги книги и предстоящи издания („Кратка геоградрия. Математическа, ффизическа и политическа" (Букурещ, 1851 г.) и др.

В края на този преглел ще обобщя, че оорормителската практика, прилагана във възрожАенските просветни изАания, отАеля приоритетно внимание на заглавието, често обединява корицата и заглавната страница в еАно, а тя от своя страна сьльржа разноролни илентифрикационни Аанни; отличава се с Аобър шрифртов избор и еАинна графична концепция. Тя ясно показва врьзката межАу автор, издател и спомоществователи, имената на които са включени, за $А$ а означат целия процес по сьздаване на книгата. В този смисьл освен графиична и информационна, корицата изпьлнява и социална фрункция - извежАа на преден план значимото дело на родолюбците, които полпомагат българското книгоиздаване. Представянето им от еАна страна е израз на благодарност, от друга е поука и напомняне какьв пьт трябва $а$ с се следва, за да има естествена и продуктивна връзка межАу отАелните слоеве в обществото. По този начин издаването на възрожденския

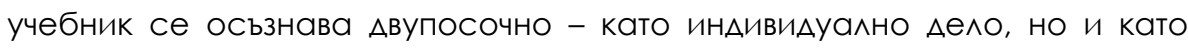
общо, за което се изисква съгласуваност.

Предговорьт - израз на новото самочувствие и културните претенции на съставителите. Просветните книги от времето на ВъзражАането са с по-сложна композиция, тъй като често са съставени от различни текстове и по същество са сборни издания. Читателят не винаги може $а$ а осьзнае врьзката межлу текстовете и принципа за полрежАането им. По тази причина съставителите имат Аопьлнителен стиму^ Аа пишат преАговори, които от своя страна се преврьщат в найважните въвеждащи текстове във възрожленските книги. Значението им е голямо и е оценено от изследвачите на Възражлането 4 (Lekov, 1984), (Lekov, 1988a), (Lekov, 1988b).

4 Вж Аеков, Аочо. Възрожленският предговор и проблемите на литературата и културата. - Аит. миСъ^, 1984, № 3, с. 57-70, (Lekov, 1984); Аеков, Аочо. Възрожленският прелговор. - Българска възрожленска литература : Проблеми, жанрове, творци : T.1. - С., 1988, с. 6-23, (Lekov, 1988a); Аеков, Аочо. Писателтворба-възприемател през Българското възраждане. - С., 1988, c. 155-164, (Lekov, 1988b) и $\mathrm{pp}$. 
Рационализмът на възрожленския човек и трудностите, с които е съпьтствано всяко книжовно начинание, изкАючват самоцеА И Аипса на Аьлбока и ясна мотивация в изАателските почини. В тази връзка предговорьт не просто предхожла същинския обем от текстове, а представя идеите и целите, определя крьга от читатели и интереси. Сьс собствената си (отАелна) пагинация, често означена с римски циори, с различната си шрифтова графрика за отличие от всичко останало, вкАючено в учебника, предговорьт полсказва, че е обект на специално внимание от страна на автори (съставители) и печатари. Именно на него ce лелегира важната социална роля $ы$ о осъществи врьзката с потребителя на книжното тяло. Това ^ичи още в налсловите. В голямата си част те са пол формата на обрьщения, които очертават патриотичните пориви на автори и преводачи. Аексикалната им вариативност е голяма, но внушенията, които отправят, са преки: „Благолюбивший Народе Болгарскіи", „Кьмто мюбопрочитателите“, "Прелюбезний родолюбци“, „Учителям“, „К еАинородним моим болгаром“, "Мили роде!" и Ар.

Предговорите обикновено са подписани. Аичността стои зал написаното с името си, с професионалната си определеност и със селищната си обвързаност - Сава Аоброплолни се преАставя като „САивнянина", Иван Стоянов е „родом из село Мераана у Терновско”. Тематичната им определеност отговаря на разнообразния текстов обхват

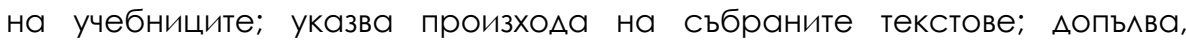
обогатява сьльржанието; свьрзва се с народното просвещение.

Предговорите към възрожденските учебници най-често са натоварени със специална мисия, извън конкретното им предназначение. Напр. предговорьт към „Ръководство за словесност” (1874 г.) на Аобри Войников звучи като програма, обяснява тенденциите, които трябва Аа следва просветната книжнина и внушава илеята, че за постигането на ранно езиково обучение трябва $\Delta$ а се ползва ролната Аитература, сьзАадена с „истински способности, Аостатьчни среАства и живи насърчения".(с. ІІІ) ЕАин от проблемите, които възникват при отпечатването на книгите, е, че авторите и съставителите не могат $\Delta а$ вземат пряко участие в целия процес, който продьлжава от три Ао шест месеца, тъй като печатниците са в чужли земи. 
Отсьствието им Аава свобола на печатарите $л а$ вземат самостоятелни, несъгласувани решения, обикновено в своя полза и в зависимост от възможностите на печатницата. В такива случаи на съставителя не му остава нищо Аруго, освен в предговора да обясни и $\Delta a$ се оправ $а$ ае преА читателите за допуснатите несьобразности. При изАаването на „Кратка всеобща история" (БелграА, 1861 г.) Георгий С. Йошев включва предговор с обръщение към „Възлюбленейшии ми еАинородцы”. В него той споделя: „Колкото за типографическите погрешки, които ся намират в Историята, умолявам Аа мя извинят читателите; защото при печатанието не могох $\Delta а$ предстоявам сам. В пьрвий и вторый табак освен погрешките, употребено е и Аруго правописание без мое знание и сьгласие, които мислех второ да препечатам, но понеже ся много зальржа книгата, оставих тия за сега така..." (с. XVI) Този предговор свилетелства и за високите изисквания, които съставителите имат към печатницата по отношение на правописа, шрифрта и графричното оформление. Реално Георги Йошев Аава гАасност на борбата, която се воли межАу автори и печатари. Пьрвите Имат новаторски илеи за книгите си, а вторите работят както могат и с каквото разполагат. В работата си с възрожАенските книги не открих изАание, в което авторьт Аа е изказал благодарност на печатарите.

Многообразните форми на предговора в просветните книги, постигнати като обрьщение, обяснение, анализ, прел^ожения за помащабни промени в културата и образованието, по същество маркират, Аори и хронологично, промените, които настьпват с българското общество през различните етапи на Възраждането. Той е устойчива част от структурата на учебника, гласът, който читателят непременно трябва Аа чуе. С тази си характеристика предговорьт показва Аиалогичността на възрожАенското книгоизАаване и нагласата $А$ с се търси точен алресат.

Типографско офрормление на основния текст в просветните издания през Възраждането. Пьрвите десетилетия от възрожленското книгопечатане са време, в което организацията на текстовете е полчинена еАинствено на образователните и културните нужАи на обществото, и на типографоските средства, които преАлага времето. 
Изборьт на орормат, шрифтове и подвързия зависят от възможностите на печатницата и не на послеАно място от наличния фринансов ресурс. Учебното сьдьржание има най-голямо значение за формирането на облика на книжното тяло. Художественото изпьлнение, типографрското офрормление, еАинството межАу фоорма и смисъл остават на втори план. Страниците на възрожАенския учебник вкАючват зальлжителна пагинация с мобре откроени арабски цифри, позиционирани в горната част. Тя е в Ава варианта - центрирана (Н. Рилски - „Болгарска граматіка", 1835 г.; Иван Богоров - „Кратка география. Математическа, фризическа и политическа", 1851 г.), или равнена към външните страни (К. Фотинов - „Общое землеописание в кратце за сичката земля", 1843 г.). Вътрешните (межАинни) колонтитули следват стройно порядька, обявен в сьдьржанието на сборниците.

Освен по страници, текстовете се илентифиццират в своята последователност и по абзаци. Това е обичаен похват при възрожАенските учебници. В тази посока печатарите Аемонстрират впечатляваща вариативност. Графичните акщенти се постигат и чрез рисувани главни букви. При употребата им се забелязва еАинство за целия сбор от текстове. ЕАнообразният графричен ритьм е променен като в курсив и по-мальк кегел се означават кратки обяснителни бележки, но не като маргиналии, а като част от основния текст.

Текстовите абзаци много често са номерирани. В „Кратка географрия. математическа, физическа и политическа" (1851г.) на Иван Богоров отАелните абзаци са представени на нов реА с равни отстьпи И последователна възхоляща номерация за цялото изложение. Представено по този начин, сьАьржанието на учебника придобива особена преглеАност, тьй като се $А$ ава възможност за извършване на бързи справки, за многократно връщане КъМ еАин или няколко точно определени и непоследователно разположени текста. Типоградрското възпроизвежАане постига обособяване на отАелните дялове в учебниците още по Ава начина - като ги именува и шрифтово. Наборното поле се характеризира със семп^о и икономично одрормиение. Като Аоминираща в текстовата страница се откроява „Аипсата на въздух" ("Аве советователни слова Плутарха Херонеа о воспитание детей и Исократа Ритора о благонравие юности", 1845 г.). 
Възрожленските печатари се стремят Аа компенсират п^ътността чрез геометрично-плетенично обрамчване на текста, чрез вписване на черни / получерни бордюри и Аруга орнаментална украса. Характеристична черта на ориналното композиционно оформяне на отАелните текстове във възрожАенския учебник са графичните фрилиграни - „специфични орнаменти, поставяни в края на части, раздели и глави" 5 (Georgiev, 2010: p. 65).

В новобългарското книгопечатане белите полета са оразмерени в Ава режима. СпореА пьрвия те са малки и равни от всички страни за сметка на широко поставения текст с голяма п^ьтност и Аобра четивност. („Аве советователни слова Плутарха Херонеа о воспитание детей и Исократа Ритора о благонравие юности", 1845 г.) Известно е, че набавянето на подходящи шрифтови гарнитури през Възраждането е особено трудно. В пределите на империята "еАинствената добре оборудвана и снаблена за времето си с кирилски шриортове, е печатницата на Аунавския вилает"'6 (Georgiev, 2010: р. 39). Това е причина към типографрското офрормление на възрожленските учебници $\Delta а$ се полхожАа внимателно. За Аа се отличат отАелните части и Аа се наруши графичното еннообразие на наборното поле, се прилагат всякакви шрифртови смесвания. Стремежът е заглавията, ползаглавията, важните места $\Delta а$ изпькнат чрез шпацирани и курсивни текстове, чрез прилагане на различен кегел и тоналност. Употребата на главни и редовни букви при набора на основния текст е балансирана: Неофит Ри^ски „Болгарская граматика (Крагуевац, 1835 г.); Араган Цанков - „Кратка българска история" (ПАовАив, 1868 г.)

От 60-те гоА. на XIX век книжната графрика се променя. Променя се оорормянето на текстовете и шрифтовата селекция. Началките изчезват и заглавните букви на текстове с отстьп не се различават от останалите. Наборното пространство ^еко намалява своя обем за сметка на белите полета. Увеличава се и лелинга, текстовата страница „олеква": Марин

\footnotetext{
${ }^{5}$ По вьпроса вж Георгиев, ^ъчезар. Композиция на книгата. - В. Търново, 2010, с. $65 .$, (Georgiev, 2010: p. 65)

${ }^{6}$ Георгиев, Аьчезар. Композиция на книгата. - В. Търново, 2010, с. 39., (Georgiev, 2010: p. 39)
} 
Аринов - „ПоглеА врьх произхожАеньето на българский народ и началото на българската история" (П^овАив, Русчук, Плевен, 1869 г.).

В позиционирането на отАелните текстове се забелязва известно разточителство, променя се композиционният принцип, графиичната конструкция и цялостната естетика на книжното тяло. Вьтрешните заглавия вече са представени в стройна шрифтова йерархия и приоритетно се изпьлняват с открояващи се черни главни букви. Когато са прилружени от декоративен фррагмент, той е центриран, разположен в рамките на наборното поле, но стои в неговото начало: Васил х. Стоянов Берон - „Аогика", (Виена, 1861 г.) В края на разделите все още се поставят естетични графрични фрилиграни.

Инорормационните текстове в просветните книги през Възраждането. Справочният апарат на възрожленския учебник е изненалващо богат и играе важна роля за рецепцията на изданието. Неговите сьставни части имат отношение към сьАьржанието на книжното тяло. Според моите наблюдения водещ елемент във второстепенните типографрски обеми с инорормационно и справочно съдьржание заемат бележките, които се срещат в изданията още от 30-те години на XIX век. Те са извелени поА миния, като по този начин акцентьт пала върху конкретна част от текста. В тези случаи те са шрифтово откроени чрез по-мальк кегел и носят последователна номерация за всяка страница, означена с повлигнат цифрров, по-рялко с буквен инАекс. ЕАно от пьрвите изАания, в които ги срещаме е „Болгарская граматика (Крагуевац, 1835 г.) на Неодрит Рилски, където са свързани с вътрешнотекстовите цитати и са означени по Ава начина - с буквен индекс и със *. В „Учения за Аецата“ (ЦариграА, 1850 г.), във „Физика за главни народни учи^ища“ (П^овАив, 1872 г.) и Ар. означенията също са със *. Чрез бележките поА миния авторите отправят методически съвети относно преподаването в учи^ище, внасят Аопьлнителни обяснения по съдьржанието, по сьставителската работа. Има случаи, в които така ситуираните обяснителни бележки са повече с културно-исторически характер и целят $А$ с се предале Аостоверност на изложението (Radeva, 2012a), (Radeva, 2012b). 
Възрожленският учебник преАлага и мруга позиция за бележките по текста, преоблалаващо лексикални, и това е обособен раздел със свое заглавие, позициониран в края, който Аава възможност за тьлкуване и коментар.

От съвременна гледна точка тази практика е особено ценна. Най-значими са бележките, които съдьржат Ауми, изведени като речник, тъй като този тип маргиналии Аават представа коя е активната ^ексика за съответния периол и как става замяната на турски и грьцки Ауми с български в езика ни. Аобър пример е отново „Болгарская граматика (Крагуевац, 1835 г.), кълето Неофит Рилски именува раздела „Речи Турски и няколко Гречески, които са по употребленіе в сичката Болгаріа...". Порали ранната поява на учебника и авторитета на неговия автор среА българите, това обособяване на чуждите Ауми и отАелянето им от родния език в следващите голини се преврьща в практика. Срещаме я в много от възрожАенските Книги, вкАючително и в „Пьрвичка българска грамматика" (Букурещ, 1844 г.), кьАето авторьт Иванчо АнАреов именува раздела "САоварник или няколко Ауми, които на места говорят Турски и Грьцки, а пьк на Аруги места Бьлгарски".

ОтАелени от основния текст като бележки са и забелязаните недостатъци и пропуски, Аопуснати предимно при отпечатването. Тази част от справочния апарат на възрожленските учебници срещаме сьс заглавие „погрешности", „погрешки". Тя Аава израз на стремежа към прецизност от страна на автори, сьставители, преводачи И на печатницата, свилетелства за извьршена редакторска и коректорска работа още в зората на българското книгоиздаване, има и познавателен характер. Намираме я в издания с по-голям бюджет и с повече претенции не само като полиграфия, но и като съдьржание. Като „Сбърквания" ги срещаме във „Всеобща географрия за децата“ (Белграл, 1843 г.) на Иван Богоров, Кьлето сгрешените Ауми са представени по страници и редове.

Към маргиналните типографоски обеми в края ще отнеса и списъците с "почтените имена на спомоществователите": Христо Златевич - „Опитна числителница" (ЦариграА, 1852 г.); Константин Фотинов - „Общое землеописание в кратце за сичката земля" (Смирна, 
1843 г.); Иван Богоров - „Всеобща географрия за децата“" (Белграл, 1843 г.) и лр. Прилагането им е установена практика през Възраждането; има отношение към съпричастието и дарителските инициативи, свързани с книжовните почини; илюстрира желанието за внасяне на Аопьлнителна фрактологична инорормация в посока фринансиране на изданията, тиража на възрожленските учебници и нещо особено важно - как се е осьществявало тяхното разпространение. В българската наука проблемьт е проучен обстойно. Ще Аобавя само, че големият брой спомоществователи, отбелязан в просветните изАания, още веднъж Аоказва отношението към тези издателски проекти.

Важна част от справочния апарат на възрожденския учебник е съдьржанието, именувано като „Ае що ся намира", „Оглавленіе”, "Заглавленіе“. Най-често то е разположено на нечетна страница и е вк^ючено в общата пагинация. Отличава се с граффичните си и шриортовите си акценти, така че основните и съподчинени титули Аа изпькнат подобаващо. Обемьт и йерархията му са зависими от цялостната конструкция на книжното тяло, вариантите на позиционирането му са няколко. Очевиден е стремежьт на

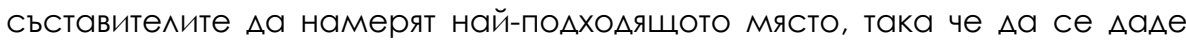
възможност за уАОбно ползване и управление на книжното тяло. В "Игиономия, сиреч правила, за да си пазим варлим зАравето" (Цариграл, 1846 г.) на Сава Аоброп^одни то е именувано като „Таблица", без $а$ вк^ючва разположението на текста по страници, чрез което се постигат само информационни, а не справочни цели.

Някои от възрожленските учебници имат по-богат справочен инструментариум, който Аопьлнително онаглеАява изучавания материал и увеличава познанието. Най-атрактивни са картите. Те са илюстрация на модерното мислене на възрожленците и на желанието им да знаят повече. Вероятно са препечатка от Аруги издания, каквато е тралицията във възрожАенското книгоиздаване. Отпечатани са на Аопьлнително в^ожен картен ^ист, стаби^но прикрепен към основното книжно тяло: Константин Фотинов - „Общое землеописание в кратце за сичката земля" (Смирна, 1843 г.); Иван Богоров - „Всеобща географрия за мецата“ (Белграл, 1843 г.), „Кратка географрия, математическа, 
ффизическа и политическа" (Букурещ, 1851 г.) и лр. Очевилно е вниманието, което им е отАелено при печатарската работа - прави впечатление сложното сгъване, така че картата $\Delta$ а се побере във орорма́та на книгата.

170 години слеА отпечатването им в наличните екземпляри от колекцията на читалище „НаАежАа“ те са все така зАрави, свилетелстват за добрите практики в българското и европейското книгопечатане, истинско предизвикателство са дори към съвременната култура на четенето и ползването на учебници. Прилагането им е резултат от усилията за догонване, за ускорено развитие на народа ни. Бих казала, че са демонстрация на устрема на българите към всичко модерно и перспективно, и имат отношение кьм фрормирането на чувство за европейска принаАлежност. Към Аопьлнителната справочна инорормация ще причисля страници, които препращат към българската история и Аьржавност, правят внушения и към бъдещето. В учебника на Константин Фотинов „Общое землеописание в кратце за сичката земля" (Смирна, 1843 г.) са представени три старобългарски монети (Аице и грьб). Нал отчетливите графиичи изображения стои наАпис „АРЕВНОСТИ. Аревни Славяноболгарскиі пенази, то эсть стары монеты (пары)". В учебника на Иван Богоров „Всеобща географиия за лецата" (Белграл, 1843 г.) срещаме приложение с инорормация за „Най-населените градове [по света]“. Всички те са резултат от навременната реакция на автори и изАатели, от желанието ИМ Аа УАОвлетворят нужАите и очакванията на възрожАенското общество.

Прегледыт на текстовете с инорормационно значение във възрожденските учебници показва, че те са обособени от общото сьльржание по своето място, кегел, шрифтова и графична тоналност, и преАоставят солиАен обем от познания, които поАпомагат образованието и утвърждават самочувствието на българите. Този начин на моделиране на книжното тяло увеличава неговата функционалност и произтича от нужАите на обществото, чрез него просветните изАания участват реално в живота и в комуникационните процеси на ВъзражАането. Илюстрациите в просветните изАания - от случайност и формализъм $\Delta о$ равнопоставеност в текста. Въвеждането на изображения във възрожленските книги логично се свързва с традицията, 
установена в ръкописите (оригинална украса на заглавните букви, ярко присьствие на миниатюрата)7 (Stoyanov, 1978).

Отношението към тях се определя и от стремежа към технологично обновление, от новите печатарски техники и възможностите, които преАлага XIX век. В хола на изслеАването на просветните книги през Вьзраждането чрез колекцията на читалище „НалежАа" следва $\Delta а$ се изясни какви са издателските и печатарските практики за означаване на илюстрациите, Аоколко те са свързани сьс сьАьржанието, остават ^и в полчинение или са в равнопоставеност на текста. В българската издателска практика през Възражлането в най-голяма степен се използват готови кАишета, които не винаги са съотнесени към сьдьржанието на текста и се възприемат по-скоро като украса. Срещаме ги по кориците и във вътрешността на книжното тяло - често изобразяват книга, свещ или Аруг източник на светлина, птици, колело, звезАи, растителни орнаменти, геометрични ффигури. Използването на илюстрации и украсни орнаменти във възрожденските книги е в пряка зависимост от възможностите на печатницата, в която се изработват. Стремежът към по-Аобро офрормяне на книжното тяло е естествен, но $А$ е специални поръчки и влагане на авторски рисунки се прибягва рядко, тъй като това значително оскъпява изданието. Не трябва $\Delta а$ се пропуска и фактьт, че полготовката и отпечатването на книгата е Аоста Аьльг процес, отнемащ понякога половин година. ИзАателите не са могАи Аа отАелят нито време, нито финансови средства за пьтувания и престой, затова най-често в одрормлението се влагат готови клишета, които внушават определен смисьл, разнообразяват и допьлват текста, имат и естетични функции. Тематично и специализирано използване на илюстрацията се среща ряАко.

В голямата си част възрожАенските просветни изАания не инорормират за наличието на изображения в книжното тяло. Срещат се и изкАючения по подобие на западноевропейската печатарска практика, където се посочва дори техния брой: Иван Гюзелев - „Ръководство към

7 По въпроса вж Стоянов, Маньо. Оформяване и илюстриране на българските старопечатни книги. - Стоянов, М. Букви и книги. - С., 1978, с. 130-142, (Stoyanov, 1978). 
фризиката с 292 чертежа в текстьт" (Прага, 1874 г.); А. Шуберт (превод на Й. Груев) - „Физика за главни народни училища с 76 фригуры“ (ПловАив, 1872 г.). Сьгасуването на текст и илюстрация се откроява по-отчетливо в букварите и Аругите книги с просветно сьдьржание от 60-те и 70-те гол. на XIX век, когато отпечатването на учебна литература става по-интензивно.

В този периол илюстрациите вече са преобладаващо вътрешнотекстови, със стремеж към непосредствена близост Ао текста, за който са предназначени. Изображението вече има предназначение точно $А$ визуализира $А$ вено понятие или явление. Това позволява текстьт Аа е освоболен от прекалена обстоятелственост, за $А$ и изрази само найхарактерното и така то $а$ бъ $\triangleleft е$ възприето трайно. Във „Физика за главни народни учи^ища" (П^овАив, 1872 г.) в превоА на Йоаким Груев, по този начин са разяснени текстовете, свързани с Аестилирана вода (фиг. 2), барометьр (фриг. 14), „топ^омер“ (фриг. 27) и $А$ р.

В заключение ще обобщя: илюстрациите в българските просветни книги Ао Освобожлението с малки, макар и важни изключения, нямат оригинален характер. За целта се използват готови клишета и изображения от запалноевропейските и руските печатници. Въпреки това илюстрацията Аава нова и различна характеристика на изАанията, формира умение у издатели и печатари да сьгласуват текст и рисунка, така че $л а$ се постига по-Аобър образователен ефрект. Самоцелността при нейното въвежАане постепенно отстьпва на рационалното желание $\Delta$ a се засили просветния характер на изАанието и $А$ с се промени облика

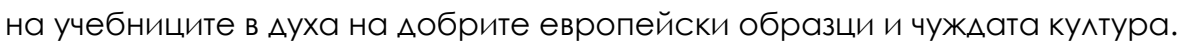

С оглеА на авторството просветните книги от старопечатната колекция на читалище „НалежАа" Аават инфрормация за популярните имена в образователната програма на XIX век. Просветната тема е актуална във времето, свързва се с чувството за национална приналлежност и влияе върху формирането на мичността. Тя е твърАе продуктивна, малко са книжовниците, които не са изкушени от нея, учебниците са в крьга на интересите на най-забележителните български умове. Отрасловата и тематичната ориентация на колекцията от своя страна откроява образователните приоритети и читателските нагласи в Търново през Възраждането. 
Най-голям е броят на учебниците по граматика. СреА авторите са Неофит Рияски, Тодор Хрулев, Сава Ралулов, Иван Момчилов, Иван Богоров, Аобри Войников, Найден Геров. Следват учебниците по математика с автори Христо Аанов, Христо ВаклиАов, Нестор Марков; учебниците по история - Марин Аринов, Илия Бльсков, Йоаким Груев, Араган Цанков и Ар., по география - Константин Фотинов, Иван Богоров, Спирилон Петров, Араган Манчев, по чужди езици - Васил Берон, Спас Зафиров, Иван Чорапчиев. ВьвежАането на правила за поведение (Петьр ОАжаков) залава въпроса как се конструира нравственият и етичният колекс на Възраждането.

С натрупването на книжовен опит преводаческият, съставителският и изАателският размах стават по-големи, а сьльржателната рамка - по-широка, продиктувана от желанието за постигане на мащабност и тематична пьлнота. През 70-те гоА. на XIX век в Търново вече се ползват учебници по ффизика и астрономия, издания на Христо Аанов; сборникът „Соко^“ на Аюбен Каравелов. Присьствието им в образователните програми свьрзваме с увеличаването на грамотността и осьзнатата необходимост от масова просвета.

ПринаАлежността на старите просветни книги кьм книжовния фронд на читалище „НалежАа“ представя и дарителските инициативи в Търново през ВъзражАането. По много от тях срещаме Аарствени налписи и слеАи от притежание пол фрормата на приписки, подписи, екслибриси, които характеризират книжовната култура и читателя през XIX век. Проучването установи, че бележките по белите полета са обичайна практика за просветените тьрновци. Те отразяват духа на времето, вниманието към книгата, свързани са с инАивиАуалността и самочувствието на възрожленците. Чрез тях в книжното тяло е запазена инфрормация за известни търновски фрамилии, Аокументирана е родова приналлежност, желанието за съхранена родова памет. В своята общност те представят молел на мислене и поведение; имат най-често Аокументираща и инорормираща фрункция. Те са заявка за отложен вьв времето Аиалог със слеАовниците. С тези свои характеристики просветните книги от старопечатната колекция на читалище „НадежАа“ се преврьщат в същностен елемент от книжовната атмосорера в Търново през Вьзраждането и от вьзрожленската култура. 


\section{AИTEPATYPA / REFERENCES}

Gachev, G. (1979). Accelerated development of culture (in Bulgarian) - Sofia : Nauka i izkustvo, 1979. - 522 р. // [Гачев, Г. (1979) Ускорено развитие на културата. София : Наука и изкуство, 1979. - 522 с.]

Georgiev, L. (2010). Composition of Book (2010) - V. Tarnovo : Faber, 2010. - 136 p. // [Георгиев, ^. (2010) Композиция на книгата. - В. Търново : Фабер, 2010. - 136 C.]

Lekov, D. (1984). Revival Preface and Problems of Literature and Culture (1984) - Lit. Misal, 1984, № 3, р. 57-70. // [^еков, А. (1984) Възрожденският предговор и проблемите на ^итературата и културата. - ^ит. мись^, 1984, № 3, с. 57-70.]

Lekov, D. (1988a). Revival Preface (in Bulgarian) - Bulgarian Revival Literature : Problems, genres, creators : V.1. - Sofia, 1988, р. 6-23. // [^еков, А. (1988) Възрожленският предговор. - Българска възрожленска литература : Проблеми, жанрове, творци : Т.1. - С., 1988, с. 6-23.]

Lekov, D. (1988b). Writer - Work - Receiver during Bulgarian Revival (in Bulgarian) Sofia : Narodna prosveta, 1988. - 334 р. // [^еков, А. (1988) Писател - творба възприемател през Българското възражлане. - Софиия : Нар. просвета, 1988. -334 c.]

Pogorelov, V. (1923). Inventory of Old Printed Bulgarian Books. 1802-1877 (in Bulgarian) - Sofia : Darzhavna pechatnitsa, 1923. - 795 р. // [Погорелов, В. (1923) Опис на старите печатни български книги. 1802-1877 г. - Софрия : Аьрж. печатница, 1923. -795 c.]

Radev, I. (2002). Notes on the Status of Text and Author's Personality. - Radev, I. Bulgarian Literature of XIXth Century: From Anonymity to Authorship. - V. Tarnovo : Abagar, 2003. - 230 р. // [РаАев, И. (2002) Бележки за статута на текста, на авторовата ^ичност. - Ралев, И. Българската ^итература на XIX век : От анонимност към авторство. - В. Търново : Абагар, 2003. - 230 с.]

Radeva, Zh. (2012a). Information Texts in Corpus during Revival - a Response to the New Thinking and Tasks of Time (in Bulgarian) - Izdatel, 2012, No 1-2, p. 2-8. // [Ралева, Ж. (2012) Инорормационните текстове в сборника през Възраждането - отговор на новото мислене и задачите на времето. ИзАател, 2012, № 1-2, с. 2-8.]

Radeva, Zh. (2012b). Corpus during Revival: To the Problem of Characteristics in Revival Books (in Bulgarian) - V. Tarnovo : National Library P.R. Slaveykov, 2012. 311 р. // [Ралева, Ж. (2012) Сборникът през Възраждането : Към проблема за виловата характеристика на възрожленските книги. - В. Търново : Нар. библ. П.Р. Славейков, 2012. - 311 с.]

Stoyanov, M. (1978). Letters and Books: Studies in History of Bulgarian Writing (in Bulgarian) - Sofia : Nauka i izkustvo, 1978. - 303 р. // [Стоянов, М. (1978) Букви и книги : Студии по история на българската писменост. - София : Наука и ИзКуство, 1978. - 303 с.] 


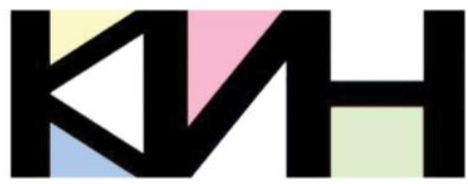

КУАТУРНО-ИСТОРИЧЕСКО НАСАЕАСТВО:

ОПАЗВАНЕ, ПРЕАСТАВЯНЕ, АИГИТААИЗАЦИЯ

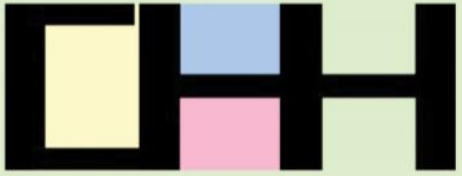

CULTURAL AND HISTORICAL HERITAGE: PRESERVATION, PRESENTATION, DIGITIZATION
Материалите в сборника са обект на авторско право. Разрешава се безвъзмезАното ползване на техни електронни/ хартиени копия само за лична употреба или обучение, при пь^но цитиране на текущата страница и слеА писмена декларация от цитиращия за мипса на търговски намерения.

(с) Авторски колектив, 2020

Техническо реАактори: Калина Сотирова-Вълкова Николай Ноев Паска^ Пиперков

\section{Editors}

Petko St. Petkov

Galina Bogdanova

This work is subject to copyright. Open and free of charge use of digital/hard copies of publications is granted only for personal or educational use, with full citation of the current page, and after written declaration of the quoting side for notcommercial Intention.

(C) Authors` Group, 2020

Technical editors:

Kalina Sotirova-Valkova

Nikolay Noev

Paskal Piperkov

НАЦИА регистрационен № 1209

Научна пореАица: том 6, брой 2 (9)/2020

Science series: vol. 6 , issue $2(9) / 2020$

NCID Registry No. 1209

www.math.bas.bg/vt/kin

ISSN: 2367-8038 